\title{
Life Model in Mutual Exchange Experiences in Alcohol Consumption of Mahasarakham University Students, Thailand
}

\author{
Buavaroon Srichaikul* \\ Mahasarakham University, Thailand
}

Submission: February 5, 2018; Published: April 24, 2018

*Corresponding author: Buavaroon Srichaikul, Faculty of Public Health, Mahasarakham University, Thailand, Tel: +66-43-754-241;

Email: buacanada@gmail.com

\begin{abstract}
Objectives: Alcohol consumption among Public Health students in Mahasarakham University has been increasing rapidly every year. Therefore it is very important to solve this problem of students in preventing their alcohol consumption. We had introduced "Life Model in Mutual Exchange Experiences in Alcohol Abuse Program "in order to change their behaviors.

Study design: In this research was quasi- experimental study which combined the activities with lectures, video, dialogues of role playing from the training materials were supported by the National Police Organization and Mahasarakham Police Station including the trainers from Police Academy and Mahasarakham Public Health Promotion Team.

Methods: The samples consisted of 114 students selected by simple random sampling method from Public Health Students, Mahasarakham University, Thailand. The samples were divided into an experimental group ( $\mathrm{n}=57)$ and comparative group $(\mathrm{n}=57)$ and was introduced with the intervention program of the above especially Life Model in mutual exchanges the experiences, demonstrations, group discussion, practice and home visits.

Results: The results were calculated with pair t- test and independent t- test before and after the experiment between the experimental group and comparative group. The results showed higher mean scores of knowledge in harmful use of alcohol consumption, perception in self-controlled alcohol use, social support power, and behavior in alcohol binge drinking among the students than before the experiment with statistically significant difference at $\mathrm{p}$-value 0.05 .

Conclusion: This program can decrease alcohol drinking behavior of Public Health Mahasarakham University students and should be further introduced among other universities or community colleges in Thailand.
\end{abstract}

Keywords: Life model; alcohol; Public health students; Exchange experiences; Quasi experiment

\section{Introduction}

Alcohol consumption among Public Health students in Mahasarakham University has been increasing rapidly every year. It has been found from secondary data from 2011-2012 survey research which was $15 \%$ increasing gradually. Therefore it is very important to solve this problem of students in preventing their alcohol consumption. This study was aimed at using the program of Role Play in Mutual Exchange Experiences in Alcohol Abuse of Mahasarakham University Students Awareness Model, Thailand to decrease the numbers of alcohol drinkers among the university students at Mahasarakham University [1].

\section{Methods}

The study was Quasi-experiment research and consisted of 908 populations of Public Health students, Mahasarakham University from bachelor degree program, aged between 1726. The samples were selected by calculated sample sizes with estimation of mean scores in drinking alcohol behavior in each independent sample groups [2].

$$
\mathbf{n}=2 \mathrm{~s}^{2} \frac{(\mathrm{Za}+\mathrm{zb})^{2}}{(\mathrm{~m} \mathbf{1}-\mathbf{m} \mathbf{2})}
$$

$\mathrm{n}=$ number of samples in each group

$\mathrm{Za}(0.05)=1.64 \mathrm{p}$-value at $0.05, \mathrm{Zb}+1.28 \mathrm{~S} 2=11$.

$\mathrm{m} 1=$ mean of MSU alcohol abuse drinkers behavior before experiment $(\mathrm{m} 1=46.71)$

$\mathrm{m} 2=$ mean of MSU alcohol abuse drinkers behaior after experiment $(\mathrm{m} 2=43.05)$

$$
\mathbf{n}=\frac{2(11.25)(1.64+1.28)^{2}}{(46.71-43.05)}=52.41
$$


Including $10 \%$ lost (5 persons) therefore the sample of experimental and comparison group are $=57$ persons in each group total samples=114 Period of experiment was 12 weeks (showed below)

\section{Experimental group X}

01[ 03

Comparison group $\mathrm{X}$

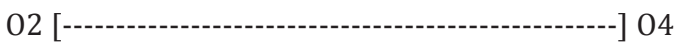

01, 02 was data collected before the experiment

03, 04 was data collected after the experiment

$\mathrm{X}$ was all activities of Program in each period during the experiment as follows:

$\mathrm{X} 1$ was activities of organizing the meeting and explaining how the program was running.

$\mathrm{X} 2$ was the activities of teaching and lecturing about knowledge of harmful in alcohol drinking to the students by the experts from Police Department officers

$\mathrm{X} 3$ was the exchanging the experiences of success in giving up drinking alcohol trained by the group of researchers

X4 was the activities of using the Prototype positive and negative models of students or people who had been drinking and faced the disaster experiences until they succeeded in giving up alcohol consumption

$\mathrm{X} 5$ was the activities of values and expectation in end results of the program

X6 was the activities of verbal persuasion, innovation of emotional supports from the group of researchers

$\mathrm{X} 7$ was the activities of using social support powers by researchers [3].

\section{Population and sample}

Population and samples were selected in simple random sampling method includes males and females who had completed qualified in the inclusion and exclusion criteria.

\section{Inclusion criteria}

- $\quad$ Students who were willing to participate the program until the end of program.

- $\quad$ Students who have been drinking alcohol (beginner and/ or frequency drinking).

- Students who had no difficulties in hearing, visualization or speaking and be able to communicate well.

Interviewing with closed questionnaires was the research instrumental of this study which were derived from the reviewing literatures and theories [4,5]. The questionnaires consisted of 4 parts which were a. Knowledge of harmful in alcohol use with 15 items. The score of 1 is right answer and 0 for wrong answer. (Bloom,1968) high (23-28), moderate (17-22) and low level (0-16)

b. Perception in self controlled of alcohol use with 17 items and 3 levels of scores which were high (2.34-3.00), moderate (1.67-2.33) and low level (1.00-1.66).

c. Social support power with 16 items and 3 levels of scores which were high (2.34-3.00), moderate (1.67-2.33) and low level (1.00-1.66).

d. Behavior in preventing alcohol binge drinking with 30 items and 3 levels of scores which were high (2.34-3.00), moderate (1.67-2.33) and low level (1.00-1.66).

The program was introduced during 12 weeks in the experiment. The contents of this program were as follow:

Success experiences in giving up alcohol drinking with self control, lecturing of harmful in alcohol binge drinking, observing from the Prototype model who had faced the bad experiences and problems due to drinking alcohol, organizing exchanging the experiences in small group of discussion, good persuasion of not beginning of alcohol drinking, supporting to decrease the stress not using alcohol as solutions, giving sympathy and support with home visiting or dormitory visiting, recording the students problem and giving good advice in solving problems, using medias: flyers, video, posters on alcohol topics [6].

Test for the quality of instrument (Interviewing questionnaires)

i. The first questionnaire of knowledge of harmful in alcohol use tested in construct validity by interviewing with 3 experts with passed the IOC index and also passed the content validity test. The questionnaires also were tested reliability with Kuder Richardson KR=20 which showed the value of 0.75 which had been acceptable.

ii. The second questionnaire of perception in self controlled of alcohol use also had 0.78 in reliability.

iii. The third questionnaire of social support power also had 0.85 in reliability.

iv. The fourth questionnaire of Behavior in preventing alcohol binge drinking also had 0.79 in reliability. The study began from 8th April 2012 to 9th July 2012. The duration of implementation and preparation was 12 weeks.

\section{Results}

Data were analyzed by mean of descriptive and inferential statistic which were percentage, mean, frequency, standard deviation, Paired-sample t-test and Independent-sample t- test which showed in the below (Table 1-4). 


\section{Global Journal of Pharmacy \& Pharmaceutical Sciences}

Table1: Comparison of Mean scores in Knowledge of harmful in alcohol use, Perception in self controlled of alcohol use, Social support power and Behavior in alcohol binge drinking between comparative group before and after the experiment.

\begin{tabular}{|c|c|c|c|c|c|}
\hline \multirow{2}{*}{ Result } & \multicolumn{3}{|c|}{ Comparative Group $(n=57) t$} & \multirow{2}{*}{ Df } & \multirow{2}{*}{ P-Value } \\
\hline & Mean & SD & Level & & \\
\hline \multicolumn{6}{|c|}{ 1. Knowledge Of Harmful In Alcohol Use } \\
\hline $\begin{array}{l}\text { Before the } \\
\text { experiment }\end{array}$ & 20.39 & 2.82 & Moderate & 0.256 & $56<0.799$ \\
\hline After the experiment & 20.37 & 2.80 & Moderate & & \\
\hline
\end{tabular}

2. Perception in self controlled of alcohol use

\begin{tabular}{|c|c|c|c|c|c|c|}
\hline $\begin{array}{c}\text { Before the } \\
\text { experiment }\end{array}$ & 2.31 & 0.29 & Moderate & 0.056 & $56<0.961$ \\
\hline After the experiment & 2.32 & 0.31 & Moderate & \\
\hline \multicolumn{7}{|c|}{ 3. Social support power } \\
\hline $\begin{array}{c}\text { Before the } \\
\text { experiment }\end{array}$
\end{tabular}

*p-value 0.05 .

Table 2: Comparison of mean scores in Knowledge of harmful in alcohol use, Perception in self controlled of alcohol use, Social support power and Behavior in alcohol binge drinking between experimental group before and after the experiment.

\begin{tabular}{|c|c|c|c|c|c|}
\hline \multirow{2}{*}{ Result } & \multicolumn{3}{|c|}{ Experimental Group $(n=57) t$} & \multirow{2}{*}{ Df } & \multirow{2}{*}{ P-Value } \\
\hline & Mean & SD & Level & & \\
\hline \multicolumn{6}{|c|}{ 1. Knowledge of harmful in alcohol use } \\
\hline $\begin{array}{l}\text { Before the } \\
\text { experiment }\end{array}$ & 20.7 & 2.99 & Moderate & -16.317 & $56<0.001$ \\
\hline After the experiment & 27.33 & 0.74 & high & & \\
\hline \multicolumn{6}{|c|}{ 2. Perception in self controlled of alcohol use } \\
\hline $\begin{array}{l}\text { Before the } \\
\text { experiment }\end{array}$ & 2.26 & 0.30 & Moderate & -13.388 & $56<0.001$ \\
\hline After the experiment & 2.83 & 0.10 & Moderate & & \\
\hline \multicolumn{6}{|c|}{ 3. Social support power } \\
\hline $\begin{array}{l}\text { Before the } \\
\text { experiment }\end{array}$ & 2.31 & 0.42 & Moderate & -7.721 & $56<0.001$ \\
\hline After the experiment & 2.75 & 0.13 & high & & \\
\hline \multicolumn{6}{|c|}{ 4. Behavior in alcohol binge drinking } \\
\hline $\begin{array}{l}\text { Before the } \\
\text { experiment }\end{array}$ & 2.39 & 0.28 & high & -7.927 & $56<0.001$ \\
\hline After the experiment & 2.58 & 0.18 & Moderate & & \\
\hline
\end{tabular}

${ }^{*}$ P-Value 0.05

Table 3: Comparison of mean scores in Knowledge of harmful in alcohol use, Perception in self controlled of alcohol use, Social support power and Behavior in alcohol binge drinking between experimental group and comparative group before the experiment.

\begin{tabular}{|c|c|c|c|c|c|}
\hline \multirow{2}{*}{ Result } & \multicolumn{3}{|c|}{ Before the Experiment $\mathbf{( n = 5 7}$ )t } & \multirow{2}{*}{ Df } & P-Value \\
\cline { 2 - 5 } & Mean & SD & Level & \multirow{2}{*}{-0.580} & $112<0.563$ \\
\hline $\begin{array}{c}\text { Before the } \\
\text { experiment }\end{array}$ & 20.72 & 2.99 & Moderate & howledge of harmful in alcohol use & \\
\hline After the experiment & 20.72 & 2.99 & high & & \\
\hline
\end{tabular}




\section{Global Journal of Pharmacy \& Pharmaceutical Sciences}

\begin{tabular}{|c|c|c|c|c|c|}
\hline \multicolumn{6}{|c|}{ 2. Perception in self controlled of alcohol use } \\
\hline $\begin{array}{l}\text { Before the } \\
\text { experiment }\end{array}$ & 2.26 & 0.37 & Moderate & 0.919 & $112<0.360$ \\
\hline After the experiment & 2.32 & 0.29 & Moderate & & \\
\hline \multicolumn{6}{|c|}{ 3. Social support power } \\
\hline $\begin{array}{l}\text { Before the } \\
\text { experiment }\end{array}$ & 2.31 & 0.42 & Moderate & 2.328 & $112<0.022$ \\
\hline After the experiment & 2.49 & 0.39 & high & & \\
\hline \multicolumn{6}{|c|}{ 4. Behavior in alcohol binge drinking } \\
\hline $\begin{array}{l}\text { Before the } \\
\text { experiment }\end{array}$ & 2.39 & 0.28 & high & 0.353 & $112<0.725$ \\
\hline After the experiment & 2.41 & 0.25 & high & & \\
\hline
\end{tabular}

${ }^{*}$ P-Value 0.05 .

Table 4: Comparison of mean scores in Knowledge of harmful in alcohol use, Perception in self controlled of alcohol use, Social support power and Behavior in alcohol binge drinking between experimental group and comparative group after the experiment.

\begin{tabular}{|c|c|c|c|c|c|}
\hline \multirow{2}{*}{ Result } & \multicolumn{3}{|c|}{ After the Experiment $(n=57) t$} & \multirow{2}{*}{ Df } & \multirow{2}{*}{ P-Value } \\
\hline & Mean & SD & Level & & \\
\hline \multicolumn{6}{|c|}{ 1. Knowledge of harmful in alcohol use } \\
\hline $\begin{array}{l}\text { Before the } \\
\text { experiment }\end{array}$ & 27.33 & 0.74 & high & -18.114 & $112<0.001$ \\
\hline After the experiment & 20.37 & 2.80 & Moderate & & \\
\hline \multicolumn{6}{|c|}{ 2. Perception in self controlled of alcohol use } \\
\hline $\begin{array}{l}\text { Before the } \\
\text { experiment }\end{array}$ & 2.84 & 0.10 & High & -11.7765 & $112<0.001$ \\
\hline After the experiment & 2.31 & 0.32 & Moderate & & \\
\hline \multicolumn{6}{|c|}{ 3. Social support power } \\
\hline $\begin{array}{l}\text { Before the } \\
\text { experiment }\end{array}$ & 2.75 & 0.13 & Moderate & -10.434 & $112<0.001$ \\
\hline After the experiment & 2.27 & 0.33 & high & & \\
\hline \multicolumn{6}{|c|}{ 4. Behavior in alcohol binge drinking } \\
\hline $\begin{array}{l}\text { Before the } \\
\text { experiment }\end{array}$ & 2.58 & 0.18 & high & -9.077 & $112<0.001$ \\
\hline After the experiment & 2.25 & 0.20 & Moderate & & \\
\hline
\end{tabular}

*P-Value 0.05

\section{Results}

This research was found that the use of Role Play in Mutual Exchange Experiences in Alcohol Consumption of Mahasarakham University Students Awareness Model was very applicable in preventing the students to entering the stage of alcohol drinking and alcohol frequency drinks. The student $s$ had gained the higher mean scores level in Knowledge of harmful in alcohol use, Perception in self controlled of alcohol use, Social support power, Behavior in preventing alcohol binge drinking. All 4 hypothesis of these variables were compared between experimental group after the experiment and before the experiment showed significant statistical differences at p-value 0.05 by using Independent sample t-test statistical analysis and also were compared between experimental group and comparison group after the experiment and before the experiment showed significant statistical differences at p-value 0.05 by using pair-sample t-test statistical analysis.

This study can reveal that the program of Role Play in Mutual Exchange Experiences in Alcohol Consumption of Mahasarakham University Students Awareness Model can change the Knowledge of harmful in alcohol use, Perception in self controlled of alcohol use, social support power, Behavior in preventing alcohol binge drinking to higher level and gained more scores than before the experiment. The results can show the benefits of decreasing quantity of alcohol drinking consumption among Mahasarakham University Students, Faculty of Public Health.

\section{Discussion}

We also found that this program can create the participatory action among the students and could solve the student's 
problems without the involvement of alcohol intakes. The study also revealed that the program could increase the social supports strongly and there was the decreasing in the number of drinking alcohol students after the experiment and after following up the program. The suggestions of this study should initiate the continuous future program and following up the result by residential visits frequently. Therefore the program of Knowledge of harmful in alcohol use, Perception in self controlled of alcohol use, Social support power, Behavior in preventing alcohol binge drinking should be applied in other groups of students in various demographics.

\section{Acknowledgement}

We would like to give the special thanks to Faculty of Public Health, Mahasarakham University for giving the research fund, all participating students from faculty of Public Health, Mahasarakham University and also with great deal of appreciation to all police trainers from Police Department, Mahasarkham province. This research has been approved from ethical committee from Ministry of Public Health and has no competing interest with anyone.

\section{References}

1. Hastings G, Brooks O, Stead M, Angus K, Anker T, et al. (2010) Failure of self regulation of UK alcohol advertising. BMJ 340: b5650.

2. Smith LA, Foxcroft DR (2009) The effect of alcohol advertising, marketing and portrayal on drinking behavior in young people: systematic review of prospective cohort studies. BMC Public Health 9: 51.

3. Anderson P, de Bruijn A, Angus K, Gordon R, Hastings G (2010) Impact of alcohol advertising and media exposure on adolescent alcohol use: a systematic review of longitudinal studies. Alcohol Alcoholism 44(3): 229-243.

4. Pongdej S (2007) Behavior of Alcohol Consumption in severe abuse between couples: Alcohol Problem Research Organization.

5. Srirat L (2008) The impact study of alcohol advertisement for adolescence community.

6. Oraphan S (2005-2007) The impact of alcohol drinking surveillance impact and correlation factors related teenager behaviors of Thailand.

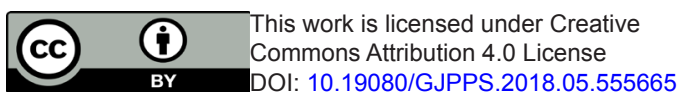

Your next submission with Juniper Publishers will reach you the below assets

- Quality Editorial service

- Swift Peer Review

- Reprints availability

- E-prints Service

- Manuscript Podcast for convenient understanding

- Global attainment for your research

- Manuscript accessibility in different formats

( Pdf, E-pub, Full Text, Audio)

- Unceasing customer service

Track the below URL for one-step submission https://juniperpublishers.com/online-submission.php 